\title{
Screen for stage-specific expression genes between tail bud stage and heartbeat beginning stage in embryogenesis of gynogenetic silver crucian carp
}

\author{
YAo Hua SHI, Jun LIU, JiAn Hong XIA, Jian FANG GUI* \\ State Key laboratory of Freshwater Ecology and Biotechnology, Wuhan Center for Developmental Biology, Institute \\ of Hydrobiology, Chinese Academy of Sciences, Wuhan 430072, China
}

\begin{abstract}
A systemic study was initiated to identify stage-specific expression genes in fish embryogenesis by using suppression subtractive hybridization (SSH) technique. In this study, we presented a preliminary result on screen for stage-specific expression genes between tail bud stage (TBS) and heartbeat beginning stage (HBS) in gynogenetic silver crucian carp ( Carassius auratus gibelio). Two SSH plasmid libraries specific for TBS embryos and HBS embryos were constructed, and stage-specific expression genes were screened between the two stages. 1963 TBS positive clones and 2466 HBS positive clones were sampled to PCR amplification, and 1373 TBS and 1809 HBS PCR positive clones were selected to carry out dot blots. 169 TBS dot blot positive clones and $272 \mathrm{HBS}$ dot blot positive clones were sequenced. Searching GenBank by using these nucleotide sequences indicated that most of the TBS dot blot positive clones could not be found homologous sequences in the database, while known genes were mainly detected from HBS dot blot positive clones. Of the 79 known genes, 20 were enzymes or kinases involved in important metabolism of embryonic development. Moreover, specific expressions of partial genes were further confirmed by virtual northern blots. This study is the first step for making a large attempt to study temporal and spatial control of gene expression in the gynogenetic fish embryogenesis.
\end{abstract}

Key words: SSH, embryonic development, differential expression genes, gynogenesis, silver crucian carp.

\section{INTRODUCTION}

Embryonic development is a progressive process, and the process is regulated by differential gene activity. All the somatic cells in an embryo or individual are derived from the fertilized egg by successive rounds of mitotic cell division. The differences between cells must therefore be generated by differences in gene expression[1],[2]. It is generally believed that particular embryonic morphological stage is related to particular gene expression. Thus, to understand the mechanism of embryonic morpho-

* Corresponding author: Fax: 0086-27-87875132, e-mail: jfgui@ihb.ac.cn

Received March-7-2002 Revised April-26-2002 Accepted May10-2002 logical construction and pattern formation, it is necessary to identify and analyze genes that are activated at special development stage and/or tissues and organs.

In the early of 1980 ' s, Sargent and Dawid (1983) had analyzed differential gene expression by subtraction cloning[3]. In recent years, mutagenesis screens, such as random insertion of exogenous DNA, targeted mutagenesis in embryonic stem (ES) cells and random mutagenesis screens using irradiation ray or chemical materials, have been performed in several model organisms and have identified many essential genes required for normal embryonic development [4-6]. However, these strategies have been undertaken on a limited scale and several model organisms.

Suppression subtractive hybridization (SSH)[7] has been widely demonstrated to be a very successful 
technique for studying differential gene expression [8-12]. By the way of hybridization and PCR of mRNA or cDNA of different tissues, organs, development stages or individuals, the general genes are removed and low abundant specific genes can be enriched. Therefore, we can get specific expression gene fragment libraries that have been enriched.

Fishes, the biggest and most diverse community in vertebrates are good experimental models for studies of cell and developmental biology by many favorable characteristics[13]. Natural gynogenetic silver crucian carp (Carassius auratus gibelio) is a special species that have some particular characters different from other natural gynogenetic vertebrates. There are about 5-20\% males in natural populations of silver crucian carp[14]. The spindle behavior was also special during the oocyte maturation. The chromosomes were first arranged to become a tripolar spindle, then the tripolar spindle was turned round and reunited and finally a bipolar spindle was formed[15]. Therefore, silver crucian carp had been considered as a unique system for studying mechanism of oocyte maturation, sex determination and embryonic development[16-19]. In order to understand the mechanism of embryonic development behind the gynogenetic silver crucian carp, we have initiated a systemic study to use suppression subtractive hybridization technique to identify stagespecific expression genes in embryogenesis. In this study, we present a preliminary result on screen for stage-specific expression genes between tail bud stage (TBS) and heartbeat beginning stage (HBS) in embryogenesis of gynogenetic silver crucian carp. It is the first stage for making a large attempt to study temporal and spatial control of gene expression in the gynogenetic fish embryogenesis.

\section{MATERIALS AND METHODS}

\section{Brood fish and embryos}

The brood fish of gynogenetic silver crucian carp, belonging to clone D, was selected from Guanqiao Experimental Station, Institute of Hydrobiology, Chinese Academy of Sciences. During reproduction season, spawning was artificially induced by two intraperitoneal injections with a mixture of acetone-dried carp pituitary, HCG and LRH-A[20]. Ovulated eggs were inseminated with sperms from red common carp Cyprinus carpio to stimulate gynogenesis[14]. The inseminated eggs were incubated in about 20oC. About 1500 embryos at tail bud stage (TBS) and at heartbeat beginning stage (HBS) from the same brood fish were re- spectively sampled for RNA extraction at about $30 \mathrm{~h}$ and $68 \mathrm{~h}$ after insemination.

\section{Total RNA and mRNA isolation}

The embryos were sampled from culture dish with forceps and washed twice with re-distillation water respectively. Then, embryos were appreciably dried with filter paper and total RNAs of each stage were respectively extracted with total RNA Extraction Kit (Pharmacia). mRNA was isolated from total RNA with PolyATtractm ${ }^{\circledR N A}$ isolation system III (Promega).

\section{Suppression subtractive hybridization}

Suppression subtractive hybridization was proceeded according to protocols of PCR-select ${ }^{T M} \mathrm{cDNA}$ Subtraction Kit (Clontech): 2mg mRNA of TBS and HBS embryos were reverse transcribed into single strand cDNA and double strand cDNA respectively. The resulting cDNAs were digested by Rsa I and then extracted with phenol and chloroform. The Rsa I digested cDNA was served as driver cDNA. $1 \mu \mathrm{l}$ driver cDNA of each stage was diluted with sterile water and divided into two portions. One portion was ligated with adaptor 1 while the other portion was ligated with adaptor 2R. Such adaptor-ligated cDNAs were served as testers. Two hybridizations were then performed. In the first, an excess of driver cDNA was added to each sample of tester of another stage. During the second hybridization, the two primary hybridization samples of the same stage were mixed together without denaturing, and freshly denatured driver cDNA of another stage is added to further enrich for differentially expressed sequences. After that, two steps of PCR amplifications were performed. The PCR products were cDNAs which non-specific expression gene cDNAs have been removed and stage-specific expression gene cDNAs have been enriched.

\section{PCR analysis of subtraction efficiency}

$\alpha$-tublin gene was used to confirm the reduced relative abundance of SSH libraries following the PCR selection procedure. Primers of $\alpha$-tublin gene were designed according to the conserved domains in fish. PCR parameters were $94^{\circ} \mathrm{C}$ for $30 \mathrm{~s}, 55^{\circ} \mathrm{C}$ for $30 \mathrm{~s}$, $72^{\circ} \mathrm{C} 50$ s on Perkin Elmer PCR System 2400 for 20, 25, 30, and 35 cycles, and then an additional extension at $72^{\circ} \mathrm{C}$ for $5 \mathrm{~min} .8 \mu \mathrm{l}$ of PCR products from each reaction for 20, 25, 30, and 35 cycles were represented on $0.8 \%$ agarose $/ \mathrm{EtBr}$ gel.

\section{SMART cDNA library construction}

$1 \mu \mathrm{g}$ mRNA from TBS and HBS embryos was respectively transcribed into single strand SMART cDNA with SMARTTM PCR cDNA Synthesis Kit (Clontech) according to the procedure of library construction. $1 \mathrm{ml}$ single strand SMART cDNA was diluted into $400 \mu \mathrm{l}$, and the other single Strand SMART cDNA was synthesized into double-strand SMART cDNA.

\section{Cloning and dot blot hybridization}

Second PCR products of TBS and HBS were directly cloned into vector of pGEM-T (Promega), which would be transferred into Top-10 of E. Coli and screened by blue and white colonies. White colonies were selected and PCR amplifications 
were performed with primers of nested PCR primer 1 (5' TCGAGCGGCCGCCCGGGCAGGT-3' ) and nested PCR primer 2R (5' -AGCGTGGTCGCGGCCGAGGT-3' ). Equal volume of $0.6 \mathrm{~N}$ fresh $\mathrm{NaOH}$ was mixed with $2 \mathrm{ml} \mathrm{PCR}$ product, and two identical Hybond $\mathrm{N}^{+}$nylon membranes were made by loading $0.5 \mathrm{ml}$ of the denatured PCR product of each clone on the same location. After neutralizing for $5 \mathrm{~min}$ in $0.5 \mathrm{M}$ Tris- $\mathrm{HCl}(\mathrm{pH} 7.5$ ), and washing in $\mathrm{H}_{2} \mathrm{O}$, the blotted membranes were baked to cross-link the DNAs for $2 \mathrm{~h}$ at $80^{\circ} \mathrm{C} .200 \mu \mathrm{l}$ second PCR products of subtracted cDNA from each stage w ere purified with Glassmilk DNA Purification Kit (BioStar). $1 \mu \mathrm{g}$ cDNA from each stage was probed with DIG High Primer(Boehringer Mannheim). Probe preparation and hybridization were operated according to the protocol. One of the baked membranes was hybridized with probe of TBS while the other with probe of HBS. Hybridization was performed for $16 \mathrm{~h}$ with standard hybridization buffer, then stringency washing, maleic acid buffer (replaced with Tri-Hcl) equilibration, blocking, antibody binding, maleic acid buffer equilibration and then color reaction with NBT/ BCIP (SABC). These clones that display color dots only in membrane hybridization with probe of the same stage were thought as dot blot positive. Then, the dot blot positive clones were selected for sequencing.

\section{Virtual northern blots}

Based on the results of sequencing, 45 gene fragments were selected to amplify by PCR with nested PCR primer 1 and nested PCR primer $2 \mathrm{R}$. After extracting by ethanol, the amplified cDNAs were respectively used to prepare probes for virtual northern blots. $25 \mu$ l SMART cDNA products prepared respectively from TBS and HBS embryos were electrophoresed on $1.0 \%$ agarose gel, and transferred to Hybond $\mathrm{N}^{+}$nylon membrane. Then the membranes were baked at $80^{\circ} \mathrm{C}$ for about $2 \mathrm{~h}$. The baked membranes were respec-

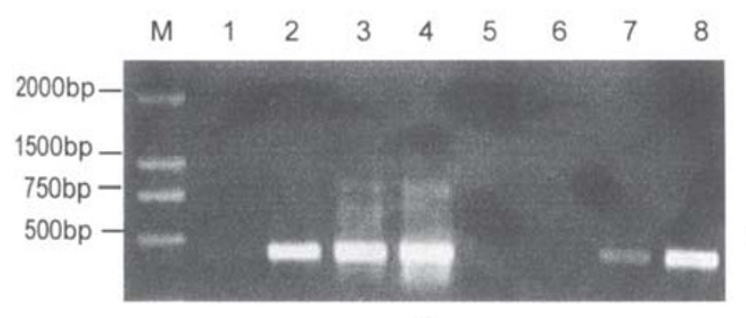

A tively hybridized with the prepared probes from different clones. Hybridization and color detection procedures were similar to that described previously[10], [11].

\section{RESULTS}

\section{Construction of the subtracted cDNA libraries}

Two subtracted cDNAs specific for TBS and HBS embryos were first evaluated by PCR analysis using a-tublin gene as probe after subtractive hybridizations were performed. As shown in Fig 1, the subtraction efficiency was obvious. For the unsubtracted cDNAs of tail bud stage, the a-tublin product could be observed at about 20 cycles, while the amplified product could be seen at about 30 cycles in the subtracted cDNAs. The abundance of $\alpha$-tublin was theoretically different about 28 between unsubtracted and subtracted cDNAs. So far as the subtracted cDNAs of heartbeat beginning stage, it was about 9 cycles later that a a-tublin product could be seen. Therefore, the abundance of $\alpha$-tublin was theoretically different about $2^{9}$ between the unsubtracted and subtracted cDNAs. These results showed that suppression subtractive hybridization between TBS and HBS embryos have effectively excluded nonstage specific expression genes. Then, two subtractive cDNA plasmid libraries specific for TBS and HBS embryos were constructed from the subtracted cDNAs.

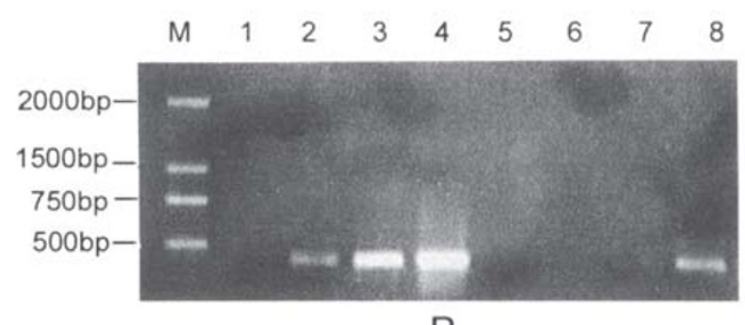

B

Fig 1. Subtraction efficiency of a-Tublin cDNA between subtracted and unsubtracted cDNAs detected by PCR.

(A) Tail bud stage (TBS), (B) heartbeat beginning stage (HBS); 1, 2, 3, 4-products of unsubtracted cDNAs, 5, 6, 7, 8-products of subtracted cDNAs; 1, 5-20cycles 2, 6-25cycles 3, 7-30cycles 4, 8-35cycles, M-maker DL-2000.

\section{Screen of the differential cDNA fragments}

Dot blotting was used to screen the differential cDNA fragments from the two subtractive cDNA plasmid libraries. 1963 white clones and 2466 white clones were respectively sampled from subtractive TBS plasmid library and HBS plasmid library to amplify the inserted cDNA fragments by PCR with primers of nested primer 1 and nested primer $2 \mathrm{R}$. 
Screen for genes in fish embryogenesis

Tab 1. Homologue searching and differential expression confirmation of the sequenced cDNA fragments from the dot blot positive clones

\begin{tabular}{|c|c|c|c|c|}
\hline $\begin{array}{l}\text { Clone serial } \\
\text { Number }\end{array}$ & $\mathrm{F}$ & Homologue gene (Accession number) & $\begin{array}{l}\text { Amino acid } \\
\text { idensity }(\%)\end{array}$ & $\begin{array}{r}\text { Differential } \\
\text { expression }\end{array}$ \\
\hline TBS1 & 1 & microsomal triglyceride transfer protein (AAH12686) & 72 & $\mathrm{~N}$ \\
\hline TBS2 & 1 & neuronal myosin light chain kinase 1 (AAB41402) & 35 & $\mathrm{~N}$ \\
\hline TBS3 & 1 & immunoglobin-like protein (NP-491290 & 21 & $\mathrm{~N}$ \\
\hline TBS4-11 & 8 & cement gland-specific protein (AAB81968) & 62 & $\mathrm{~N}$ \\
\hline TBS12 & 1 & traf2 and NCK interacting kinase, splice variant (AAF03787) & 95 & $\mathrm{~N}$ \\
\hline TBS13 & 1 & microsomal triglyceride transfer protein, $97 \mathrm{kDa}$ subunit (CAA53217) & 60 & $\mathrm{~N}$ \\
\hline TBS14 & 1 & ovary-specific MOB-like protein (AAL55655) & 83 & $\mathrm{~N}$ \\
\hline TBS15 & 1 & 40S ribosomal protein S7 (AAK95189) & 95 & $\mathrm{~N}$ \\
\hline TBS16 & 1 & survival of motor neuron protein-interacting protein 1 (Q9QZP1) & 78 & $\mathrm{~N}$ \\
\hline TBS17 & 1 & keratin (AAC38008) & 63 & $\mathrm{~N}$ \\
\hline TBS18 & 1 & hypothetical protein FLJ20296 (NP-060220) & 35 & $\mathrm{~N}$ \\
\hline TBS19 & 1 & stonustoxin alpha-subunit (AAC60022) & 32 & $\mathrm{~N}$ \\
\hline TBS20-22 & 3 & protein-glutamine gamma-glutamyltransferase (AAA63495) & 48 & $\mathrm{~N}$ \\
\hline TBS23 & 1 & hpaII tiny fragments locus 9C (NP-073564) & 64 & $\mathrm{~N}$ \\
\hline TBS24 & 1 & ubiquitin-conjugating enzyme UbcH7 (CAA04156) & 96 & $\mathrm{~N}$ \\
\hline TBS25 & 1 & annexin max3 (CAA72124) & 4 & $\mathrm{~N}$ \\
\hline TBS26 & 1 & phosphoenolpyruvate carboxykinase (AAK28384) & 76 & $\mathrm{~N}$ \\
\hline TBS27 & 1 & hypothetical 18K protein - goldfish mitochondrion (JC1348) & 60 & $\mathrm{~N}$ \\
\hline TBS28 & 1 & ribosomal protein S19 (AAG13287) & 79 & $\mathrm{~N}$ \\
\hline TBS29 & 1 & p68 RNA helicase (AAF73861) & 89 & $\mathrm{~N}$ \\
\hline TBS30-31 & 2 & propionyl-COA carboxylase beta chain, mitochondrial precursor (XP-051991) & 90 & $\mathrm{~N}$ \\
\hline TBS32 & 1 & cathepsin C(AAL48192) & 53 & $\mathrm{~N}$ \\
\hline TBS33 & 1 & PAK-interacting exchange factor beta (Beta-Pix) (Q14155) & 79 & $\mathrm{~N}$ \\
\hline TBS34 & 1 & zinc finger protein 40 (probable transcription regulator NT fin12) (NP-033581) & 56 & $\mathrm{~N}$ \\
\hline TBS35 & 1 & Uncoupling protein 2 (CAB46248) & 100 & B \\
\hline TBS36 & 1 & cytochrome c oxidase subunit 1 (BAB40350) & 93 & B \\
\hline TBS37 & 1 & cofilin (M55659) & 60 & B \\
\hline TBS38 & 1 & vacuolar protein sorting factor 4B[VPS 4-2 ATPase] (AAH03799) & 87 & B \\
\hline TBS39-41 & 3 & no obvious homologue & & $\mathrm{T}$ \\
\hline TBS42-47 & 6 & no obvious homologue & & $\mathrm{B}$ \\
\hline TBS48-169 & 122 & no obvious homologue & & $\mathrm{N}$ \\
\hline HBS1 & 1 & alpha globin type-1 (S16184) & 70 & $\mathrm{H}$ \\
\hline HBS2-3 & 2 & alpha globin type-2 (BAA34949) & 81 & $\mathrm{H}$ \\
\hline HBS4-44 & 41 & alpha globin type-3 (BAB79240) & 88 & $\mathrm{H}$ \\
\hline HBS45-52 & 8 & beta globin type-1 (AAC62069) & 80 & $\mathrm{H}$ \\
\hline HBS53-64 & 12 & beta globin type-2 (BAB79238) & 73 & $\mathrm{H}$ \\
\hline HBS65-98 & 34 & beta globin type-3 (BAB79239) & 94 & $\mathrm{H}$ \\
\hline HBS99-106 & 8 & alpha skeletal muscle actin (alpha -actin 1) (BAA08755) & 100 & $\mathrm{H}$ \\
\hline HBS107-109 & 3 & skeletal alpha-actin type-2 (BAA76668) & 98 & $\mathrm{H}$ \\
\hline HBS110 & 1 & cardiac muscle actin (CAA27397) & 97 & $\mathrm{~N}$ \\
\hline HBS111 & 1 & enteric smooth muscle gamma-actin (NP-037025) & 99 & $\mathrm{~N}$ \\
\hline HBS116 & 5 & alpha-tropomyosin (AAA49114) & 98 & $\mathrm{H}$ \\
\hline HBS117-124 & 8 & myosin light chain 1 (BAB69817) & 87 & $\mathrm{H}$ \\
\hline HBS125 & 1 & fast skeletal myosin light chain 2 (AAC32193) & 100 & $\mathrm{H}$ \\
\hline
\end{tabular}


Tab 1. Homologue searching and differential expression confirmation of the sequenced cDNA fragments from the dot blot positive clones

\begin{tabular}{|c|c|c|c|c|}
\hline $\begin{array}{l}\text { Clone serial } \\
\text { Number }\end{array}$ & $\mathrm{F}$ & Homologue gene (Accession number) & $\begin{array}{l}\text { Amino acid } \\
\text { idensity (\%) }\end{array}$ & $\begin{array}{l}\text { Differential } \\
\text { expression }\end{array}$ \\
\hline HBS126-139 & 14 & fast skeletal myosin light chain 3 (BAA12733) & 97 & $\mathrm{H}$ \\
\hline HBS140-147 & 8 & myosin heavy chain (AAF78476) & 80 & $\mathrm{H}$ \\
\hline HBS148-158 & 11 & creatine kinase M1-CK (AAC96092) & 96 & $\mathrm{H}$ \\
\hline HBS159-186 & 28 & creatine kinase M3-CK AAC96094) & 95 & $\mathrm{H}$ \\
\hline HBS187-188 & 2 & heat shock protein 70 (BAA76887) & 97 & $\mathrm{~B}$ \\
\hline HBS189 & 1 & heat shock protein HSP 90-alpha (AAD50972) & 63 & B \\
\hline HBS190 & 1 & heat shocking protein hsp90 beta (AF042108) & 97 & B \\
\hline HBS191-192 & 2 & fast skeletal muscle troponin C (AAF78473) & 95 & $\mathrm{~N}$ \\
\hline HBS193-194 & 2 & fast skeletal muscle troponin I (CAB59981) & 70 & $\mathrm{~N}$ \\
\hline HBS195 & 1 & S100-like calcium binding protein (AAC28367) & 65 & $\mathrm{~N}$ \\
\hline HBS196-202 & 7 & anterior gradient 2 (XAG-2) (NP-006399) & 72 & $\mathrm{H}$ \\
\hline HBS203 & 1 & aminoleuvlinate synthase erythroid specific isoform (AAC72835) & 97 & $\mathrm{H}$ \\
\hline HBS204-208 & 5 & desmin $(\mathrm{AAB} 03217)$ & 89 & $\mathrm{~N}$ \\
\hline HBS209-211 & 3 & $\mathrm{Na}^{+} / \mathrm{K}^{+}$ATPase alpha1A1 subunit (AAG30274) & 84 & $\mathrm{~N}$ \\
\hline HBS212-214 & 3 & collagen II A1 protein (AAA49678) & 85 & $\mathrm{~N}$ \\
\hline HBS215 & 1 & metallothionein (AAB70467) & 92 & $\mathrm{~N}$ \\
\hline HBS216 & 1 & sarcomeric muscle protein (XP-010848) & 58 & $\mathrm{~N}$ \\
\hline HBS217-219 & 3 & type II cytokeratin (AAF05847) & 96 & $\mathrm{~B}$ \\
\hline HBS220 & 1 & oocyte-type fatty-acid binding protein (AAL40832) & 86 & $\mathrm{~N}$ \\
\hline HBS221 & 1 & parvalbumin (CAC83658) & 85 & $\mathrm{~N}$ \\
\hline HBS222-223 & 2 & epidermal differentiation-specific protein (BAA01991) & 48 & $\mathrm{~N}$ \\
\hline HBS224 & 1 & matrilin-4 precursor (CAA06890) & 51 & $\mathrm{~N}$ \\
\hline HBS225-226 & 2 & alpha enolase-1 (AAG16310) & 76 & $\mathrm{~N}$ \\
\hline HBS22 & 1 & protein tyrosine phosphatase type IVA (NP-003454) & 89 & B \\
\hline HBS228 & 1 & N-acetylneuraminic acid phosphate synthase (AAF75261) & 74 & B \\
\hline HBS229 & 1 & arginine:glycine amidinotransferase (AAF61951) & 94 & $\mathrm{~N}$ \\
\hline HBS230 & 1 & $\mathrm{NAD}^{+}$- - isocitrate dehydrogenase (subunit beta) $(\mathrm{Q} 28479)$ & 90 & B \\
\hline HBS231-232 & 2 & cytochrome c oxidase subunit I (NP-008590) & 87 & B \\
\hline HBS233 & 1 & fructose-bisphosphate aldolase (CAA57729) & 80 & $\mathrm{~N}$ \\
\hline HBS234 & 1 & methylmalonate-semialdehyde dehydrogenase (AAG44988) & 74 & $\mathrm{~N}$ \\
\hline HBS235 & 1 & ornithine decarboxylase (AAG01031) & 93 & $\mathrm{~N}$ \\
\hline HBS236 & 1 & hatching enzyme EHE(BAB68513) & 56 & $\mathrm{~N}$ \\
\hline HBS237 & 1 & kelch-like protein (XM-049561) & 57 & B \\
\hline HBS238 & 1 & unnamed protein product (BAB70815) & 54 & $\mathrm{~N}$ \\
\hline HBS239 & 1 & KIAA0308 [Homo sapiens] (BAA20767) & 59 & $\mathrm{~N}$ \\
\hline HBS240 & 1 & KIAA0372 gene product [Homo sapiens](NP-055454) & 41 & $\mathrm{~N}$ \\
\hline HBS241 & 1 & hypothetical protein DFKZP 586G1123 (NP-115648) & 68 & B \\
\hline HBS242 & 1 & no obvious homologue & & $\mathrm{H}$ \\
\hline HBS243-246 & 4 & no obvious homologue & & B \\
\hline HBS247-272 & 26 & no obvious homologue & & $\mathrm{N}$ \\
\hline
\end{tabular}

Abbreviations: F-frequency of identical clones; TBS-tail bud stage; HBS-heartbeat begining stage. $\mathrm{N}$ - no virtual northern blot was done; T-TBS-specific expression confirmed by virtual northern blot; H-HBS-specific expression confirmed by virtual northern blot; B-expression in both stages confirmed by virtual northern blot. 
1373 and 1809 PCR positive clones were selected to carry out dot blotting respectively from TBS and HBS subtracted libraries. Those TBS clones that could be seen in membrane hybridized with probe of SSH cDNA of TBS but not HBS were TBS dot blot positive (Fig $2 \mathrm{~A}$ and $2 \mathrm{~B}$ ), and those HBS clones that could be seen in membrane hybridized with probe of SSH cDNA of HBS but not TBS were HBS dot blot positive (Fig $2 \mathrm{C}$ and 2D). These dot blot positive clones might be thought as differential cDNA fragments specific for TBS or HBS.
From these dot blot positive clones, 169 TBS and 272 HBS clones were selected to be sequenced respectively. The sequenced results were analyzed by searching NCBI database. From the analysis results (Tab 1), we could see that no homologue sequences were found in 129 TBS dot blot positive clones and 32 HBS dot blot positive clones, which implicates that these positive clones might be some unknown novel genes. As shown in Tab 1, 79 homologue genes have been detected, and 6 of them were hypothetical proteins that the function had not

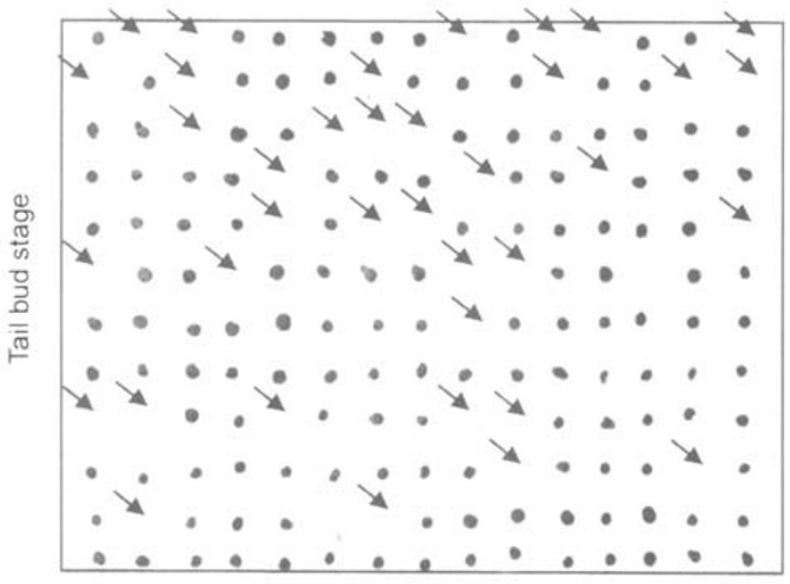

A

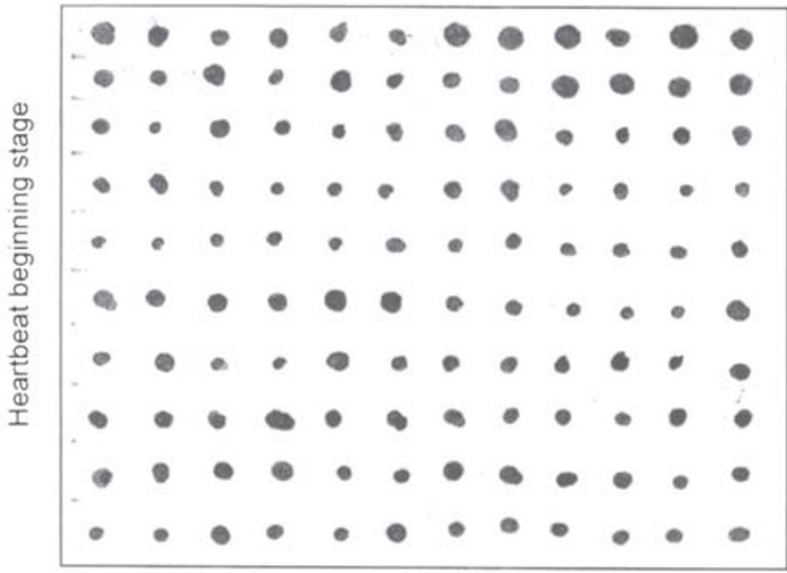

C

Hybridization with probe of heartbeat beginning stage

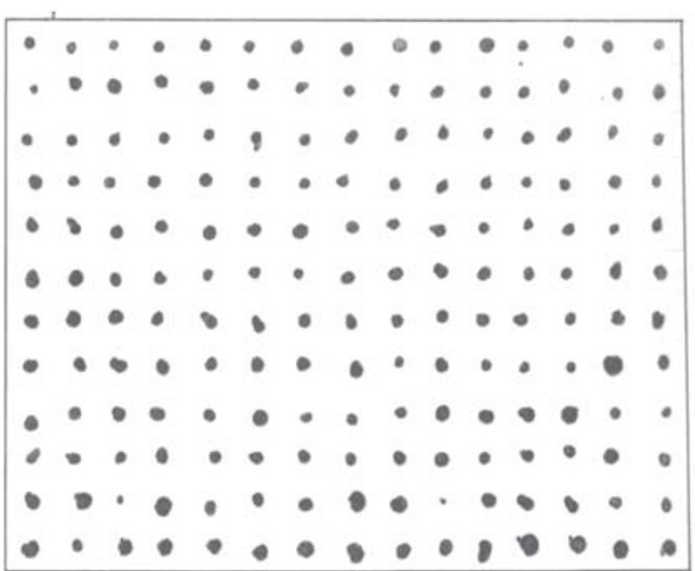

B

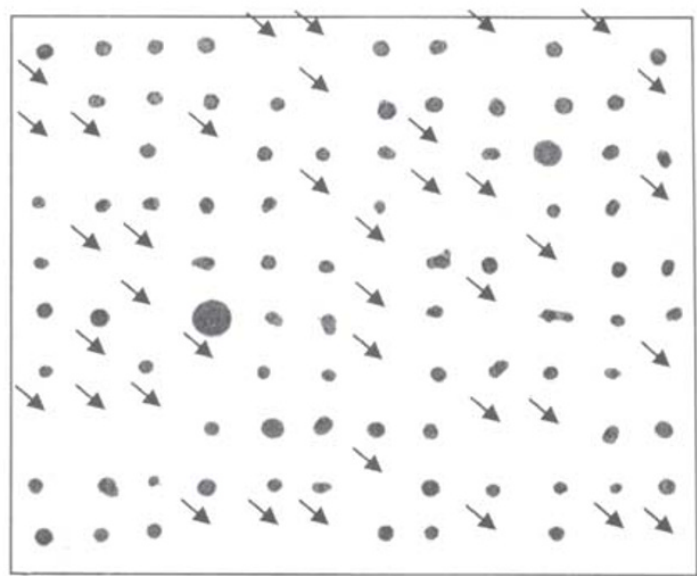

D

Hybridization with probe of tail bud stage

Fig 2. Screening of differential cDNA fragments between subtracted TBS and HBS embryo cDNA plasmid libraries with dot blots. A,B-PCR products of subtracted tail bud stage (TBS) clones; C, D-PCR products of subtracted heartbeat beginning stage (HBS) clones. A, C- hybridized with probe of SSH cDNA of HBS embryos; B, D- hybridized with probe of SSH cDNA of TBS embryos. The arrows in A and D showed the positions of dot blot positive clones of tail bud stage embryos and heartbeat beginning stage embryos in $\mathrm{B}$ and $\mathrm{C}$ respectively. 
been studied. In the known homologue genes, there were 20 enzymes or kinases. Some genes that play important role in embryonic development, such as heat shock proteins, uncoupling protein 2 , cement gland protein FAG-2 (fish anterior gradient, XAG-2 homolog), epidermal differentiation-specific protein, and fast skeletal muscle troponin, were also detected.
Additionally, several genes specific HBS embryos, such as globins and creatine kinase, were detected by very high frequencies from dot blot positive clones (Tab 1).

Virtual Northern blot confirmation of stage-specific expression genes

Virtual Northern blot results showed that not all
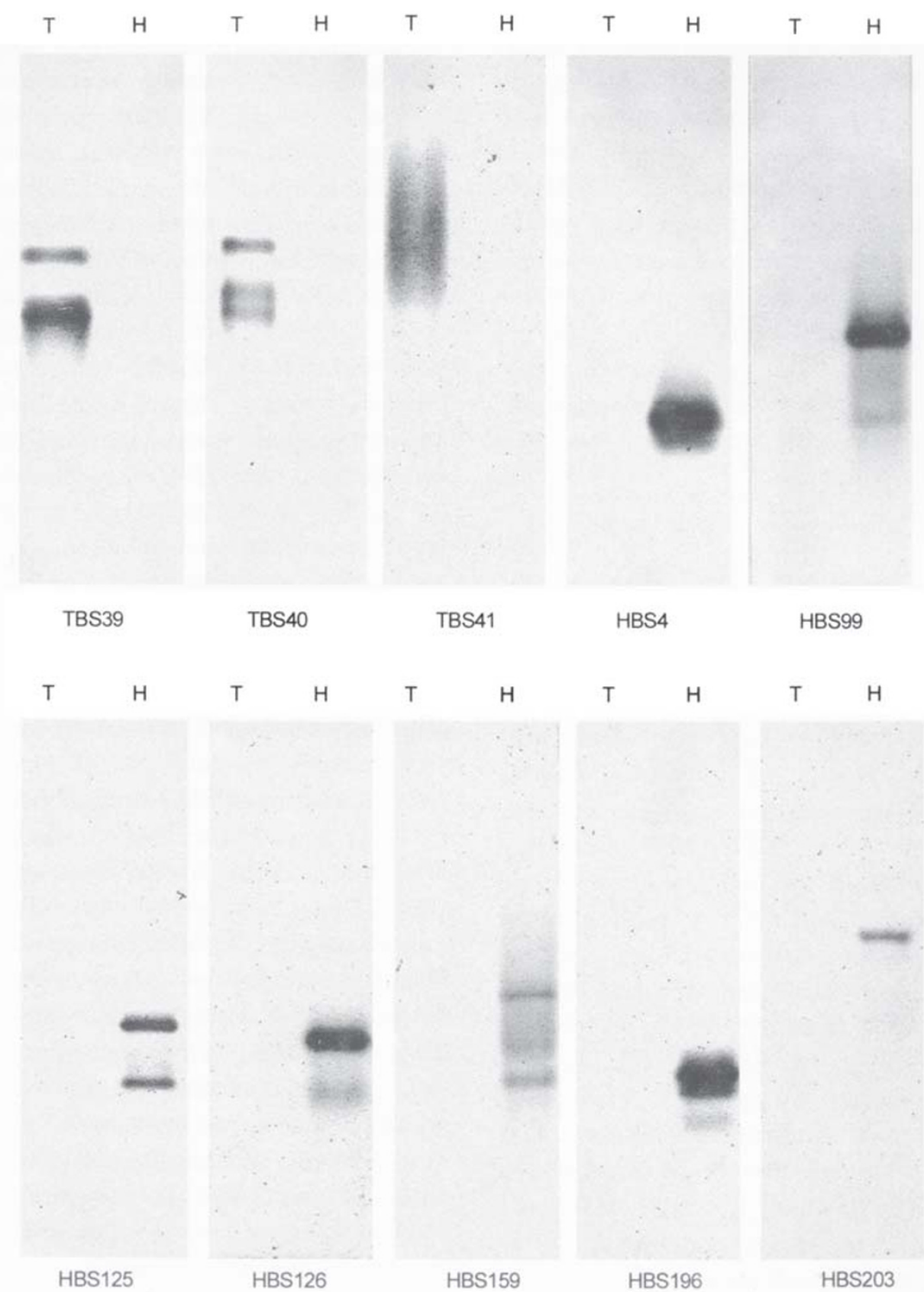

Fig 3. Confirmation of stage-specific expression genes by virtual northern blots. TBS-tail bud stage; HBS- heartbeat beginning stage. T-tail bud stage SMART cDNA, H-heartbeat beginning stage SMART cDNA. TBS40, TBS41 and TBS42 were tail bud stage-specific expression genes, and the remainders were heartbeat stage-specific expression genes (Tab 1). 
of the dot blot positive clones were stage-specific expression genes (Tab 1). Of 45 cDNA fragments that virtual northern blot had been carried out, 21 fragments were positive. The positive frequency was more than $46 \%$. Fig 3 showed 10 differentially expressed genes confirmed by virtual Northern blot. The 10 genes included 3 unknown genes specific for TBS embryos, such as TBS39, TBS40 and TBS41, and 7 known homologue genes specific for HBS embryos, such as HBS4-the alpha globin type3, HBS99-the alpha skeletal muscle actin (a-actin 1), HBS125-the fast skeletal myosin light chain 2 , HBS126-the fast skeletal myosin light chain 3, HBS159-the creatine kinase M3-CK, HBS196-the anterior gradient 2 (FAG-2), and HBS203-the Aminoleuvlinate synthase erythroid specific isoform (Tab 1). So far, all of the TBS specific expression genes confirmed by virtual Northern blot could not be found any homologues, which suggested that they might be novel genes. However, there was only one HBS specific expression gene that could not be found homologue in NCBI database.

\section{DISCUSSION}

Subtractive hybridization and differential display have been extensively applied in isolation and identification of disease relating genes, embryonic development stage-specific expression genes and genes that determine cell differentiation or organogenesis [21-23]. Although the theory of differential display is very simple, it costs too much time and the false positive rate is quite high[24],[25]. Traditional subtractive hybridization methods required several rounds of hybridization and are not well suited for the identification of rare messages[26-28] . Based on the applying of selective amplification of differentially expressed sequences, besides overcoming technical limitation of traditional subtraction methods[29],[30], suppression subtractive hybridization leads to enrichment specific-expression library. Our results showed that non-specific expression gene atublin had been reduced about $2^{8}$ and $2^{9}$ after subtraction between tail bud stage and heartbeat beginning stage respectively. It suggested that nonspecific expression genes had been gotten rid of and stage-specific expression genes had been enriched efficiently in our suppression subtractive hybridization libraries. Therefore, such suppression subtrac- tive hybridization libraries were successful. The work of isolation and identification of known or novel genes is the base of functional studying and therefore the base of embryonic development mechanism. As showed in our results, we could screen a great number of known and novel genes involved in embryonic development from these libraries. Thus, construction of subtractive libraries will be useful for studying embryonic development biology.

SMART cDNA method is a useful technique accompanying suppression subtractive hybridization. A modified oligo(dT) primer primers the first-strand synthesis reaction. When reverse transcription reaches the 5' end of the mRNA, the terminal transferase activity of reverse transcriptase adds a few additional nucleotides oligo $(\mathrm{C})$. Then, the secondstrand cDNA was synthesized with SMARTTM Oligonucleotide, which has an oligo(G) sequence at its 3 ' end. SMART cDNA can replace RNA in analysis of virtual northern hybridization and the information given by virtual northern hybridization was the same as provided by standard northern hybridization[12],[31]. This character is valuable for studying embryonic development of animal that can only spawn one time. Moreover, SMART cDNA is very useful in cloning the full length of cDNA[31]. In this work, the virtual northern blots positive rate of dot blots positive clones could reach more than $46 \%$ suggested that dot blot is effective. Such a pre-screen is necessary for cloning specific expression genes from $\mathrm{SSH}$ libraries because it can save not only much money but also valuable time.

Embryogenesis is a progressive and complex process. The early stages of embryogenesis involve cell migration and pattern formation, and lead to the formation of three germ layers (the ectoderm, mesoderm and endoderm) and developmental field. The later stages include cell specification, morphogenesis, differentiation and commitment, and result in organ formation (organogenesis)[32]. These developmental events and modules are controlled by differential gene activity. The current study was mainly concentrated on the screen for stagespecific expression genes between tail bud stage and heartbeat beginning stage in embryogenesis of gynogenetic silver crucian carp. As screened by SSH (Tab 1) and verified by virtual northern blots (Fig 3), TBS-39, TBS-40 and TBS-41 expressed at TBS 
but could not be detected at HBS. They must have been activated at earlier embryonic developmental stage, even before fertilization. After TBS, they fulfilled their mission and were degenerated between TBS and HBS. Gene transcription activity is tightly related to its function. Therefore, their instantaneous expression activity suggested that they should be regulative genes of early development stage-specific and play some important roles during the early embryonic development. Although it is necessary to supply further evidence, we can believe reasonably that TBS-39, TBS-40 and TBS-41 may involve in some early embryonic developmental events, such as cell migration or pattern formation. TBS-specific expression genes were obviously fewer than that of HBS. It might be because that once activated, gene would keep expression activity in a quite long time and most of genes expressed at TBS did not be closed at HBS.

The fact that most of HBS dot blot positive clones were identified as known genes was consistent with the extensive studies on heart and blood formation in vertebrates, especially in the model animal zebrafish[32-34]. In the sequenced HBS stage-specific clones (Tab 1), most of them were embryonic globins, myosin, or creatine kinase. These genes belong to embryonic globins family or myosin family. They were important structural proteins and regulative factors. Embryonic globins, which carry out function of transporting oxygen and nutrition for cells and tissues, are the most important constituent of circulation system[32]. Because embryonic globins are significant signals of heartbeat establishment and circulation system formation in the early vertebrate embryo, its highlighted expression revealed by this study indicated that the $\mathrm{SSH}$ library of HBS embryos is highly effective. In addition, a clone that was $97 \%$ amino acid identity to the 3 '-end of ALAS-E (aminoleuvlinate synthase erythroid specific form) has been also detected. Because ALAS-E is a speed-limited enzyme that catalyzes the first step of heme synthesis, and is erythroid-specific[35], it should be activated when embryonic globins are to be synthesized. Therefore, other genes involved in the regulative network will be able to be revealed by further studies.

In summary, we have detected some embryonic development stage-specific expression genes be- tween TBS and HBS by largely screening SSH libraries. Moreover, their specific expressions were confirmed by virtual northern blots. Full length cDNA clone and further studies on their function, such as their spatial and time expression models, will help us to understand the molecular mechanism underlying the fish embryonic development.

\section{ACKNOWLEDGMENTS}

This work was supported by the National Natural Science Foundation of China (Grant No. 30130240), the Chinese Academy of Sciences (Grant No. KSCX2SW-303).

\section{REFERENCES}

[1] Newport J W, Kirschner M W. Regulation of the cell cycle during Xenopus laevis development. Cell 1984; 37:73142.

[2] Wolpert L, Beddington R, Brockes J, Jessell T, Lawrence P, Meyerowitz E. Principles of Development. Current Biology Ltd 1998; London.

[3] Sartgent TD, Dawid I. Differential gene expression in the gastrula of Xenopus laevis. Science 1983; 222:135-9.

[4] Soriano P, Cone RD, Mulligan RC, Jaenisch R. Tissuespecific and ectopic of expression genes introduced into transgenic mice by retroviruses. Science 1986; 234:1409-13.

[5] Driever W, Solnica-Krezel L, Schier AF, Neuhauss SC, Malicki J, Stemple DL, Stainer DY, Zwartkruis F, Abdelilah S, Rangini Z, Belak J, Boggs C. A genetic screen of mutations affecting mbryogenesis in zebrafish. Development 1996; 123:37-46.

[6] Haffter P, Granato M, Brand M, Mullins MC, Hammerschmidt M, Kane DR, Odenthal J, van Eeden FJ, Jiang YJ, Heisenberg CP, Klsh RN, Furutani-Seiki M, Vogelsang E, Beuchle D, Schach U, Fabian C, NussleinVolhard C. The identification of genes with unique and essential functions in the development of zebrafish, Danio rerio. Development 1996; 123:1-36.

[7] Diatchenko L, Lau YC, Campbell AP, Chenchik A, Mooadam F, Huang B, Lukyanov S, Lukyanov K, Gurskaya N, Sverdlov E, Siebert PD. Suppression subtractive hybridization: A method for generating differentially regulated or tissue-specific cDNA probes. Proc Natl Acad Sci USA 1996; 93: 6025-30.

[8] Chu ZL, Mckinsey TA. Suppression of tumor necrosis factor-induced cell death by inhibitor of apoptosis c-IAP2 is under NF-kB control. Proc Natl Acad Sci USA 1997; 94 : 10057-62.

[9] Davis C A, Benzer S. Generation of cDNA expression libraries enriched for in-frame sequences. Proc Natl Acad Sci USA 1997; 94:2128-32.

[10] Fan LC, Yang ST, Gui JF. Differential screening and characterization analysis of the egg envelop glycoprotein ZP3 cDNAs between genogenetic and gonochoristic crucian carp. Cell Research 2001; 11(1):7-27. 
[11] Xie J, Wen JJ, Chen B, Gui JF. Differential gene expression in full-grown oocytes between genogenetic and gonochoristic crucian carps. Gene 2001; 271:109-16.

[12] Wen JJ, Xie J, Liu SG, Gui JF. Differential expression and characterization analysis of a new gene with WD domains in fish oogenesis. Science in China 2001; 44: 541-53.

[13] Zhu ZY, Sun YH. Embryonic and genetic manipulation in fish. Cell Research 2000;10(1):17-27.

[14] Jiang YG, Liang SC, Chen BD, et al. Biological effect of heterologous sperm on gynogenetic offspring in Carassius auratus gibelio. Acta Hydrobiologica Sinica 1983; 8(1): 1-13(in Chinese).

[15] Yang ZA, Li QH, Wang YF, Gui JF. Comparative investigation on spindle behavior and MPF activity changes during oocyte maturation between genogenetic and amphimictic crucian carp. Cell Research 1999; 9:145-54.

[16] Gui JF. A unique study system: gynogenetic fish Carassius auratus gibelio. Science Foundation in China 1996; 4 (1):44-6.

[17] Gui JF. Retrospects and prospects of studies on the mechanism of natural gynogenesis in silver crucian carp (Carassius auratus gibelio). Science Foundation in China 1997; 11:11-6(in Chinese).

[18] Gui JF, Liang SC, Zhu LF, Jiang YG. Discovery of two different reproductive developmental modes of the eggs of artificial multiple tetraploid allogynogenetic silver crucian carp. Chinese science Bulletin 1993; 38:332-7.

[19] Zhou L, Wang Y, Gui JF. Genetic evidence for gonochoristic reproduction in gynogenetic silver crucian carp (Carassius auratus gibelio Bloch) as revealed by RAPD assays. J Mol Evol 2000; 51:498-506.

[20] Gui JF. Fish developmental genetics and artificial propagation. In: Wu C, Gui JF (eds). Fish genetics and breeding engineering. Shanghai Scientific and Technical Press, Shanghai, p41-66.

[21] Duguin GL, Dinauer MC. Library subtraction of in vitro cDNA libraries to identify differential expressed genes in scrapie infection. Nucleic Acids Res 1990; 18:278992.

[22] Lisitsyn N, Lisitsyn L, Wigler M. Cloning the differences between two complex genomes. Science 1993; 259:946-51.

[23] Martin-Laurent F, Tuinen D. Differential display analysis of RNA accumulation in arbuscular mycorrhiza of pea and isolation of a noval symbiosis-regulated plant gene. Mol Gen Genet 1997; 256:37-44.
[24] Xie J, Zhu Y, Zhang F, Gui JF. Differential gene expression of protein kinases in oocytes between natural gynogenetic silver crucian carp and amphimictic crucian carp. Chinese Science Bulletin 1999; 44(14):1297-301.

[25] Sompayac L, Jane S, Burn TC, Tenen DG, Danna KJ. Overcoming limitations of the mRNA differential display technique. Nucleic Acids Res 1995; 23:4738-9.

[26] Hara E, Kato T, Nakada S, Sekiya S Oda K. Subtrctive cDNA cloning using oligo(dT)30-latex and PCR: isolation of cDNA clones specific to undifferentiated human embryonal carcinoma cells. Nucleic Acids Res 1991; 19: 7097-104.

[27] Hedrick SM, Cohen DI, Neilson EA, Davis MM. Isolation of cDNA clones encoding T cell-specific membrane-associated proteins. Nature 1984; 308:149-53.

[28] Sargent TD, Dawid IB. Differential gene expression in the xenopus laevis. Science 1983; 222:135-9.

[29] Diatchenko L, Lau YFC, Campbell AP, Chenchik A, Moqadam F, Huang B, Lukyanov S, Lukyanov K Gurskaya N, Sverdlov ED, Siebert PD. Suppression subtractive hybridization: A method for generating differentially regulated or tissue-specific cDNA probes and libraries. Proc Natl Acad Sci USA 1996; 93:6025-30.

[30] Gurskaya NG, Diatchenko L, Chenchik A, Siebert PD, Khaspekov GL, Lukyanov K A, Vagner LL, Ermolaeva OD, Lukyanov SA, Sverdlov ED. Equalizing cDNA subtaction based on selective suppression of polymerase chain reaction: Cloning of Jurkat cell transcripts induced by phytohemaglutinin and phorbol 12-myristate 13acetate. Anal Biochem 1996; 240:90-7.

[31] Endege WO, Steinmann KE, Boardman LA, Thibodeau SN, Schlegel R. Representative cDNA libraries and their utility in gene expression profiling. Bio Techniques 1999; 26:542-50.

[32] Thisse C, Zon LI. Organogenesis-heart and blood formation from the zebrafish point of view. Science 2002; 295: 457-62.

[33] Brownlie A, Zon L. The zebrafish as a model system for the study of hematopoiesis. BioScience 1999; 49:38292.

[34] Orkin SH, Zon LI. Hematopoiesis and sterm cells: plasticity versus developmental heterogeneity. Nature Immunology 2002; 3:323-8.

[35] Sadlon TJ, Dell' Oso T, Surinya KH, May BK. Regulation of erythroid 5 -aminolevulinate synthase expression during erythropoiesis. Int J Biochem Cell Biol 1999; 31 (10):1153-67. 